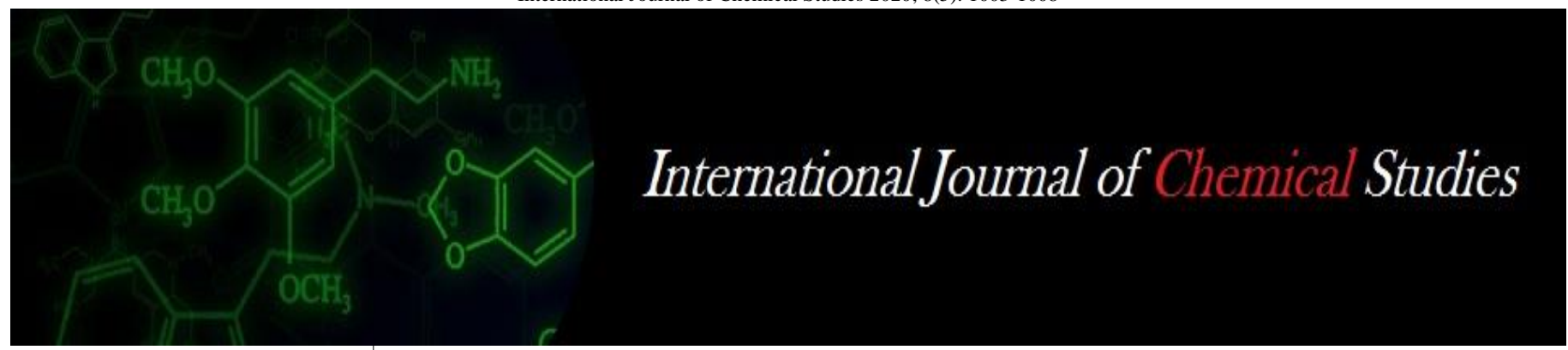

P-ISSN: 2349-8528

E-ISSN: 2321-4902

www.chemijournal.com

IJCS 2020; 8(5): 1003-1008

(C) 2020 IJCS

Received: 15-07-2020

Accepted: 26-08-2020

M Madan Mohan Goud

M.Sc. Department of

Horticulture, College of

Horticulture, Dr. Y.S.R.

Horticultural University,

Anantharajupeta, Y.S.R

Kadapa, Andhra Pradesh, India

\section{Tagore Naik}

Senior Scientist, Department of

Horticulture, Horticultural

Research Station, Dr. Y.S.R.

Horticultural University,

Mahanandi, Kurnool, Andhra

Pradesh, India

\section{K Subramanyam}

Principal Scientist, Department

Plant Pathology \& Head,

Horticultural Research Station,

Dr. Y.S.R. Horticultural

University, Mahanandi,

Kurnool, Andhra Pradesh, India

\section{Raja Naik}

Associate Professor, Department

of Horticulture, College of

Horticulture, Dr. Y.S.R.

Horticultural University,

Anantharajupeta, Y.S.R

Kadapa, Andhra Pradesh, India

\section{Jayaprada}

Assistant Professor, Department of Genetics and Plant Breeding,

College of Horticulture, Dr.

Y.S.R. Horticultural University,

Anantharajupeta, Y.S.R

Kadapa, Andhra Pradesh, India

Corresponding Author: M Madan Mohan Goud M.Sc. Department of Horticulture, College of Horticulture, Dr. Y.S.R. Horticultural University, Anantharajupeta, Y.S.R Kadapa, Andhra Pradesh, India

\section{Performance of different vegetable cowpea (Vigna unguiculata (L.) Walp) genotypes under Rayalaseema region of Andhra Pradesh}

\author{
M Madan Mohan Goud, M Tagore Naik, K Subramanyam, M Raja Naik \\ and M Jayaprada
}

DOI: https://doi.org/10.22271/chemi.2020.v8.i5n.10428

\begin{abstract}
The present exploration was carried out to study the performance of different vegetable cowpea genotypes under Rayalaseema region of Andhra Pradesh during the period from November, 2019 to February, 2020 at Horticultural Research Station, Dr. Y. S. R Horticultural University, Mahanandi, Kurnool district, Andhra Pradesh involving twelve genotypes were replicated thrice under Randomized Block Design. Among the twelve genotypes studied, Kashi Nidhi took minimum days for first flowering (39.00 days), 50\% flowering (41.67 days), first picking (51.00 days), whereas Kashi Shyamal and Kashi Gauri took maximum days for final harvest (98.00 days). Kashi Nidhi recorded maximum pod length $(42.93 \mathrm{~cm})$, maximum pod diameter $(8.60 \mathrm{~mm})$, maximum green pod weight $(21.07 \mathrm{~g})$, highest green pod yield plant ${ }^{-1}(373.20 \mathrm{~g})$, highest green pod yield plot $^{-1}(9.67 \mathrm{~kg})$, highest green pod yield ha ${ }^{-1}(161.17 \mathrm{q} \mathrm{ha}$ $\left.{ }^{1}\right)$ and highest TSS content $\left(4.94^{\circ} \mathrm{Brix}\right)$. In the present study, Kashi Nidhi is the most promising genotype with respect to yield characters and the mean values were found to be superior than the national check Kashi Kanchan for most of the characters.
\end{abstract}

Keywords: Vegetable cowpea, plant growth, yield, quality attributes

\section{Introduction}

Cowpea [Vigna unguiculata (L.) Walp] belongs to the family Leguminosae, sub-family Fabaceae and genus Vigna (Bose et al., 2003) ${ }^{[5]}$ with a chromosome number of $2 \mathrm{n}=2 \mathrm{x}=22$ (Darlington and Wylie, 1955) ${ }^{[6]}$. It is native to India (Vavilov, 1949) ${ }^{[21]}$, tropical and central Africa is also considered as secondary centre of origin, where wild races are found even now (Ng and Marechal, 1985) ${ }^{[15]}$.

Cowpea is a warm- season, self pollinated annual herb with a wide range of growth habit and response to photoperiod. It is grown throughout India for its long green pods as vegetable, seeds as pulse and foliage as vegetable and fodder. When grown for dry seeds, it is also known as black-eye pea, kaffir pea, china pea and southern bean. The cultivars grown for their immature green pods which are used as vegetable are variously known as yardlong bean, asparagus bean and snake bean.

In our country, it is cultivated mainly in Gujarat, West Bengal, Tamil Nadu, Andhra Pradesh, Kerala and Odisha. In India, the total area under beans cultivation is about 2,28,000 ha with the production of 22.77 lakh MT (NHB, 2018). In Andhra Pradesh, the total area under beans cultivation is about 4,967 ha (Agricultural Statistics at a Glance- Andhra Pradesh, 2018).

Vegetable cowpea plays an important role in Indian diet. Green tender pods form an excellent nutritious vegetable and have the potential to solve the protein problem of human diet. It is also known as 'vegetable meat'. Tender marketable pods contain $4.3 \mathrm{~g}$ protein, $2.0 \mathrm{~g}$ fiber, 8.0 g carbohydrates, $74.0 \mathrm{mg}$ phosphorus, $2.5 \mathrm{mg}$ iron, $0.9 \mathrm{mg}$ mineral matter and $13.0 \mathrm{mg}$ vitamin-C $100 \mathrm{~g}^{-1}$ of edible pods (Gopalakrishnan, 2007) ${ }^{[10]}$.

Green cowpea seeds are boiled as a fresh vegetable, or may be canned or frozen. The mature as well as dry cowpeas may also be soaked and prepared like a main dish or are usually utilized as salad fillings. Vegetable cowpea is well known for reducing plasma cholesterol within the body. It is an excellent source of suitable dietary fiber and protein. They also contain steroid compounds called phytosterol. 
These are very effective for maintaining the standard cholesterol level within the body. Regular usage of cowpea seeds helps to enhance the immunity of the body. The antioxidant properties of vegetable cowpea check the growth of cancerous cell within the body. This crop can be used as green or dry fodder crop, cover crop, green manuring crop and nitrogen fixing crop.

In India, despite the fact that a large number of genotypes and agro techniques have been developed, the productivity of vegetable cowpea has still not reached the optimum level. The high demand for this leguminous multipurpose crop is not met in the Andhra Pradesh. A number of superior vegetable cowpea genotypes were released by different State Agricultural universities and ICAR institutes but the information on suitability of genotypes to the Rayalaseema region is meager.

At present, in Andhra Pradesh, vegetable cowpea is grown in small pockets of area but potential possibilities exists to increase the area due to its suitability to the climatic condition, short duration, high yield potential, quick growing habit, high protein content, low investment, low inputs requirement, high income, adequacy of limited rainfall to mature the crop, ability to enrich soil, protect the soil from erosion and awareness among people regarding the importance of protein in the diet to avoid malnutrition.

Keeping all these aspects in view, the present investigation was undertaken to evaluate the performance of vegetable cowpea genotypes for plant growth, yield and quality attributing characters under Rayalaseema region of Andhra Pradesh.

\section{Material and Methods}

The present field experiment was conducted during the period from November, 2019 to February, 2020 at Horticultural Research Station, Dr. Y. S. R Horticultural University, Mahanandi, Kurnool district, Andhra Pradesh to study the performance of vegetable cowpea genotypes for plant growth, yield and quality attributing characters under Rayalaseema region of Andhra Pradesh. The experimental material for the present study consisted of twelve bush types of vegetable cowpea genotypes viz., Arka Suman, Arka Samrudhi were collected from IIHR-Bengaluru, Bhagyalakshmi was collected from KAU-Thrissur and IC-97797, IC-337932, IC51154, IC222810, Kashi Nidhi, Kashi Shyamal, Kashi Unnati, Kashi Gauri and Kashi kanchan (check) were collected from IIVRVaranasi. The field experiment was laid out in Randomized Complete Block Design (RCBD) with three replications with the individual plot area of $3 \mathrm{~m} \mathrm{X} 2 \mathrm{~m}$. Layout of plan showed in plate 1 . The seeds were directly sown on ridges with spacing of $60 \mathrm{~cm}$ between the rows and $45 \mathrm{~cm}$ within the row to get four rows in each plot with seven hills in each row by dibbling two seeds per hill at a depth of $3-5 \mathrm{~cm}$. Five plants in each plot were tagged randomly from the net plot of each treatment in each replication for recording the observations. The data was analyzed using computer software programmed by the method of variance outlined by Panse and Sukhatme $(1985)^{[16]}$.

\section{Results and Discussion}

The mean performance of twelve vegetable cowpea genotypes including check variety over three replications for various characters studied is presented in table 1 . The response of days taken for seed germination attribute among the genotypes varied significantly. The early germination of seed was observed in Arka Suman (4.00 days) whereas, maximum days taken for seed germination was recorded in the genotype IC-97797 (7.00 days). The genotype Arka Suman was found to be significantly earlier than check variety Kashi Kanchan (5.00 days), whereas genotypes Arka Samrudhi (4.67 days), Kasi Nidhi (5.00 days), Bhagyalakshmi (5.00 days) and Kashi Gauri (5.33 days) were found to be statistically at par with check variety Kashi Kanchan (5.00 days). The reason for the early germination may be due to genetic characteristics of the genotypes. This result is in accordance with the findings of Dipikaben et al. (2018) ${ }^{[7,8]}$ and Pawar et al. (2016) ${ }^{[17]}$ in vegetable cowpea. Highest germination per cent was recorded in the genotype Arka Samrudhi (90.48), while lowest germination per cent was recorded in the genotype Bhagyalakshmi (66.67). The genotypes Arka Samrudhi (90.48\%), Kashi Nidhi (89.29\%), Arka Suman (89.28\%), Kashi Unnati $(82.14 \%)$, IC-337932 (80.95\%), Kashi Gauri (78.57\%) and Kashi Shyamal $(77.38 \%)$ were found to be statistically at par with check variety Kashi Kanchan $(85.72 \%)$. In the present study, significant variation in germination per cent among different genotypes might be due to difference in their inherent capacity to germinate. The similar results were found by Dipikaben et al. (2018) ${ }^{[7,8]}$ and Pawar et al. (2016) ${ }^{[17]}$ in vegetable cowpea.

Maximum plant height was noted in the genotype Arka Samrudhi $(67.40 \mathrm{~cm})$, while minimum plant height was recorded in the genotype Bhagyalakshmi $(37.60 \mathrm{~cm})$. The genotypes Arka Samrudhi $(67.40 \mathrm{~cm})$, Kashi Nidhi $(66.40$ $\mathrm{cm})$, Kashi Unnati $(63.40 \mathrm{~cm})$, Kashi Gauri $(63.20 \mathrm{~cm})$, Kashi Shyamal $(62.60 \mathrm{~cm})$, IC-51154 $(62.20 \mathrm{~cm})$, IC-337932 $(61.60$ $\mathrm{cm})$ and IC- $97797(60.33 \mathrm{~cm})$ were found to be statistically at par with check variety Kashi Kanchan $(64.40 \mathrm{~cm})$. This variation might be due to differences in genetic characters or due to environmental fluctuations. The similar results were reported with the findings of Dipikaben et al. (2018) ${ }^{[7,8]}$ and Pawar et al. (2016) ${ }^{[17]}$ in vegetable cowpea. Maximum Plant height $(\mathrm{cm})$ at final harvest was recorded in the genotype Arka Samrudhi $(256.87 \mathrm{~cm})$, while minimum plant height $(\mathrm{cm})$ at final harvest was recorded in the genotype Bhagyalakshmi $(43.47 \mathrm{~cm})$. The genotypes Arka Samrudhi $(256.87 \mathrm{~cm})$, Arka Suman $(157.60 \mathrm{~cm})$ and Kashi Nidhi $(156.13 \mathrm{~cm})$ were found to be significantly superior than check variety Kashi Kanchan $(147.93 \mathrm{~cm})$ whereas, genotype Kashi Gauri $(144.87 \mathrm{~cm})$ was found to be statistically at par with check variety Kashi Kanchan $(147.93 \mathrm{~cm})$. This variation might be due to the genetic characteristic of the individual genotypes or might be due to environmental fluctuation. The similar results were reported by Dipikaben et al. (2018) ${ }^{[7,8]}$, Bhattarai et al. (2017) ${ }^{[4]}$, Srinivas et al. (2017) ${ }^{[20]}$ and Pawar et al. (2016) ${ }^{[17]}$ in vegetable cowpea. Highest number of primary branches plant $^{-1}$ at final harvest was recorded in the genotype Arka Samrudhi (7.53), whereas lowest number of primary branches plant ${ }^{-1}$ at final harvest was observed in the genotype Bhagyalakshmi (4.53). The genotype Arka Samrudhi (7.53) was found to be significantly superior than check variety Kashi Kanchan (6.33), whereas genotypes Arka Suman (6.53), Kashi Nidhi (6.47), Kashi Unnati (6.27), Kashi Gauri (6.20), Kashi Shyamal (6.13) and IC- 337932 (5.93) were found to be statistically at par with check variety Kashi Kanchan (6.33). This variation might be due to difference in their genetical setup. These results are in line with Dipikaben et al. (2018) ${ }^{[7,8]}$, Reddy et al. (2016) ${ }^{[18]}$ and Hinge et al. $(2015)^{[12]}$ in vegetable cowpea.

Significantly early flowering was observed in the genotype Kashi Nidhi (39.00 days) whereas Arka samrudhi took more number of days for first flowering (48.33 days). Here the 
genotypes Kashi Nidhi (39.00 days) and Kashi Unnati (39.67 days) were found significantly earlier than the check variety Kashi Kanchan (41.67 days), while the genotypes Kashi Gauri (41.00 days) and Bhagyalakshmi (42.33 days) were found to be at par with the check variety Kashi Kanchan (41.67 days). It is due to variation in the growth hormones of different genotypes. These results are in similar with the findings of Dipikaben et al. (2018) ${ }^{[7,8]}$, Srinivas et al. (2017) ${ }^{[20]}$, Reddy et al. (2016) ${ }^{[18]}$ and Hinge et al. (2015) ${ }^{[12]}$ in vegetable cowpea. Minimum days taken for $50 \%$ flowering was observed in the genotype Kashi Nidhi (41.67), whereas Arka Samrudhi took maximum days taken for $50 \%$ flowering (52.67 days). Here the genotypes Kashi Nidhi (41.67 days) and Kashi Unnati (42.33 days) were found significantly earlier than the check variety Kashi Kanchan (45.67 days), while the genotypes Kashi Gauri (44.67 days), Bhagyalakshmi (45.67 days), IC-51154 (46.67 days) and Kashi Shyamal (46.67 days) were found to be at par with the check variety Kashi Kanchan (45.67 days). Early 50 per cent flowering in the genotype Arka Samrudhi is due to the genetic inherent characters of the genotype and climatic diversity. These results are in similar with the findings of Srinivas et al. (2017) ${ }^{[20]}$, Reddy et al. (2016) ${ }^{[18]}$ and Hinge et al. (2015) ${ }^{[12]}$ in vegetable cowpea.

Minimum duration for first picking was obtained in the genotype Kashi Nidhi (51.00 days) followed by Kashi Unnati (52.67 days), Kashi Gauri (53.33 days), check variety Kashi Kanchan (54.33 days), Bhagyalakshmi (54.67 days), IC51154 (55.67 days) and Kashi Shyamal (55.33 days), whereas maximum days taken for first picking was observed in the genotype Arka Samrudhi (61.67 days). Among twelve genotypes, Kashi Nidhi (51.00 days) and Kashi Unnati (52.67 days) were found significantly earlier than the check variety Kashi Kanchan (54.33 days), while the genotypes Kashi Gauri (53.33 days), Bhagyalakshmi (54.67 days), IC- 51154 (55.67 days) and Kashi Shyamal (55.33 days) were found to be on par with the check variety Kashi Kanchan (54.33 days). The clear cut variation among the genotypes for the time taken for first picking is due to its inherent genetic setup, suitability of climate, atmospheric and soil conditions of the region. Such type of variation was reported by Dipikaben et al. (2018) ${ }^{[7,8]}$, Reddy et al. (2016) ${ }^{[18]}$ and Hinge et al. (2015) ${ }^{[12]}$ in vegetable cowpea. Maximum days taken for last picking was observed in the genotypes Kashi Shyamal (98.00 days) and Kashi Gauri (98.00 days) followed by Arka Samrudhi (95.67 days), Arka Suman (95.33 days), Kashi Nidhi (94.33 days), Kashi Unnati (93.67 days) and check variety Kashi Kanchan (93.33 days) whereas, the genotype IC-97797 took minimum days taken for last picking (81.00 days). Among twelve genotypes, Kashi Shyamal (98.00 days), Kashi Gauri (98.00 days), Arka Samrudhi (95.67 days) and Arka Suman (95.33 days) were found significantly superior than the check variety Kashi Kanchan (93.33 days). The variation for the above trait is due to its inherent genetic makeup. Such type of variation was reported earlier in vegetable cowpea by Dipikaben et al. (2018) [7, 8]. Maximum pod length was recorded in the genotype Kashi Nidhi $(42.93 \mathrm{~cm})$ followed by Kashi unnati (40.33 cm), check variety Kashi Kanchan (40.07 cm), Kashi Gauri $(31.87 \mathrm{~cm})$ and Kashi Shyamal $(30.33 \mathrm{~cm})$ whereas, the genotype Bhagyalakshmi produce shortest pods $(18.73 \mathrm{~cm})$. Among twelve genotypes studied, only one genotype Kashi Nidhi $(42.93 \mathrm{~cm})$ was found to be superior over the check variety Kashi Kanchan $(40.07 \mathrm{~cm})$, while the genotype Kashi unnati $(40.33 \mathrm{~cm})$ was found to be at par with the check variety Kashi Kanchan $(40.07 \mathrm{~cm})$ (Plate no. 4). Variation in pod length might be due to genetic nature and due to environmental conditions. This result is similar with the findings of Srinivas et al. (2017) ${ }^{[20]}$ and Hinge et al. (2015) [12] in vegetable cowpea. Maximum pod diameter was observed in the genotype Kashi Nidhi $(8.60 \mathrm{~mm})$ whereas, minimum pod diameter was observed in genotype Bhagyalakshmi (4.60 mm). Among twelve genotypes, Kashi Nidhi $(8.60 \mathrm{~mm})$ and Kashi Unnati $(8.20 \mathrm{~mm})$ were found to be superior over the check variety Kashi Kanchan $(7.60 \mathrm{~mm})$, while the genotypes Kashi Shyamal $(7.40 \mathrm{~mm})$ and Kashi Gauri $(7.33 \mathrm{~mm})$ were found to be at par with the check variety Kashi Kanchan $(7.60 \mathrm{~mm})$. Variation in pod diameter might be due to genetic nature and due to environment. This result is similar with the findings of Srinivas et al. (2017) [20] and Hinge et al. (2015) ${ }^{[12]}$ in vegetable cowpea. Maximum number of pods plant ${ }^{-1}$ was recorded in the genotype Arka Samrudhi (63.73), while the genotype IC-222810 gave less number of pods plant-1 (33.27). Here out of twelve genotypes none of genotypes was found to be superior over the check variety Kashi Kanchan (61.27) whereas, genotypes Arka Samrudhi (63.73), Kashi Nidhi (61.73) and Arka Suman (60.93) were found to be at par with the check variety Kashi Kanchan (61.27). Variation in number of pods plant ${ }^{-1}$ may be due to its inherent genetic set up, suitability of climate, atmospheric and soil conditions of the study region. This result is in line with Dipikaben and Kumari (2018) ${ }^{[7,8]}$ and Srinivas et al. (2017) ${ }^{[20]}$ in vegetable cowpea. Maximum green pod weight was recorded in the genotype Kashi Nidhi $(21.07 \mathrm{~g})$ whereas, lowest green pod weight was noted in genotype IC-97797 (5.73 g). Out of twelve genotypes only one genotype Kashi Nidhi (21.07 g) was found to be superior over the check variety Kashi Kanchan (19.40 g), while the genotype Kashi Unnati (20.13 g) was found to be at par with the check variety Kashi Kanchan $(19.40 \mathrm{~g})$. Variation in green pod weight ( $\mathrm{g}$ ) among genotypes may be due to its inherent genetic set up, atmospheric condition study site. Similar type of information was reported by Srinivas et al. (2017) [20], Reddy et al. (2016) [18] and Hinge et al. (2015) ${ }^{[12] ~ i n ~}$ vegetable cowpea. Highest green pod yield plant $^{-1}$ was recorded in the genotype Kashi Nidhi (373.20 g) followed by check variety Kashi Kanchan (338.33 g), Kashi Unnati (311.47 g), Kashi Gauri (309.40 g), Arka Samrudhi (298.07 g), Arka Suman (287.60 g) and Kashi Shyamal (267.80 g), while lowest green pod yield plant $^{-1}$ was recorded in the genotype Bhagyalakshmi (193.13 g). Among twelve genotypes tried, only one genotype Kashi Nidhi (373.20 g) was found to be superior over the check variety Kashi Kanchan (338.33 g) and another genotype Kashi Unnati ( $311.47 \mathrm{~g})$ was found to be at par with the check variety Kashi Kanchan $(338.33 \mathrm{~g})$. Green pod yield plot $^{-1}$ recorded was highest in the genotype Kashi Nidhi $(9.67 \mathrm{~kg})$ which was followed by check variety Kashi Kanchan $(9.02 \mathrm{~kg}$ ), Kashi Unnati $(8.39 \mathrm{~kg})$, Kashi Gauri $(8.16 \mathrm{~kg})$ and Arka Samrudhi $(8.02 \mathrm{~kg})$, while lowest green pod yield plot $^{-1}$ was recorded in the genotype Bhagyalakshmi $(5.22 \mathrm{~kg})$. Among twelve genotypes tried, only one genotype Kashi Nidhi $(9.67 \mathrm{~kg})$ was found to be superior over the check variety Kashi Kanchan $(9.02 \mathrm{~kg})$. Highest green pod yield $\mathrm{ha}^{-1}$ was recorded in the genotype Kashi Nidhi (161.17 q ha-1) followed by check variety Kashi Kanchan (152.20 q ha $\left.{ }^{-1}\right)$, Kashi Unnati (141.84 q ha-1), Kashi Gauri (136.06 q ha-1) and Arka Samrudhi (133.61 q ha-1), whereas lowest green pod yield ha-1 was recorded in the genotype Bhagyalakshmi (88.39 $\left.\mathrm{q} \mathrm{ha}^{-1}\right)$. Among twelve genotypes tried, only one genotype Kashi Nidhi (161.17 $\mathrm{q} \mathrm{ha}^{-1}$ ) was found to be superior over the check 
variety Kashi Kanchan (152.20 q ha $\left.{ }^{-1}\right)$. The difference in green pod yield plant $^{-1}$, green pod yield plot $^{-1}$ and green pod yield ha-1 may be due to its inherent genetic set up, suitability of climate, atmospheric condition and soil conditions of this region. These results are in line with Dipikaben and Kumari (2018) ${ }^{[7,8]}$, Reddy et al. (2016) ${ }^{[18]}$ and Hinge et al. (2015) ${ }^{[12]}$ in vegetable cowpea.

Highest total dry matter accumulation plant $^{-1}$ was recorded in the genotype Arka Samrudhi (119.00 g) whereas, lowest total dry matter accumulation plant ${ }^{-1}$ was observed in genotype Bhagyalakshmi $(28.00 \mathrm{~g})$. The reason for high total dry matter accumulation plant ${ }^{-1}$ in the genotypes is due to indirect effect of plant height, primary branches plant ${ }^{-1}$ and number of leaves. The similar result was found by Madhavi (2012) ${ }^{[13]}$ in vegetable cowpea. Maximum protein content was observed in the genotype IC-51154 $(4.20 \%)$ followed by IC-337932 (4.07\%), IC-222810 (4.04\%), Kashi unnati (3.98\%), Bhagyalakshmi (3.94), IC-97797 (3.91\%), Kashi Nidhi (3.88\%), check variety Kashi Kanchan (3.84\%), Arka Samrudhi (3.80\%) and Arka Suman (3.77\%) whereas, minimum protein content was observed in the genotype Kashi Gauri $(3.31 \%)$. The difference in protein content (\%) may be due to its inherent genetic set up. These results are in consonance with the findings of Mal et al. (2018) and Hinge et al. (2015) ${ }^{[12]}$ in vegetable cowpea. Maximum TSS content was recorded in genotype Kashi Nidhi (4.94oBrix) which was followed by Kashi Shyamal (4.26oBrix), IC-51154
(4.23oBrix), Kashi Unnati (4.04oBrix), IC-97797 (4.01 oBrix), Kashi Kanchan (3.99oBrix) and IC-222810 (3.85 oBrix) whereas, minimum TSS content was observed in the genotype Arka Suman (3.34oBrix). The genotypes Kashi Nidhi (4.94oBrix), Kashi Shyamal (4.26oBrix) and IC-51154 (4.23oBrix) were found to be superior over the check variety Kashi Kanchan (3.99 oBrix), while the genotypes Kashi Unnati (4.04oBrix), IC-97797 (4.01 oBrix), and IC-222810 (3.85 oBrix) were found to be at par with the check variety Kashi Kanchan (3.99oBrix). The complete variation in TSS content (oBrix) among cowpea genotypes may be due to its inherent genetic set up. Similar types of reports were informed by (Diwaker et al., 2017: Reddy et al., 2016) ${ }^{[9,18]}$ in vegetable cowpea.

The lowest mean per cent incidence of pest was recorded in genotype Arka Samrudhi (12.18\%), whereas highest mean per cent incidence of pest was recorded in genotype Kashi Gauri $(47.33 \%)$ The reason for per cent incidence of pest may be climatic conditions and resistance of genotypes. These results find the support from Gupta et al. (2019) [11] and Roy et al. (2011) ${ }^{[19]}$ in cowpea. The lowest mean per cent incidence of disease was recorded in genotype Arka Samrudhi (3.96\%), whereas highest mean per cent incidence of disease was recorded in genotype Kashi Gauri (18.91\%). The reason for per cent incidence of disease may be climatic conditions and resistance of genotypes. These results are in line with Bamabalwad et al. (2019) ${ }^{[3]}$ in cowpea.

Table 1: Mean values for various characters in vegetable cowpea

\begin{tabular}{|c|c|c|c|c|c|c|c|c|c|c|c|c|}
\hline \multirow[b]{2}{*}{$\begin{array}{c}\text { S. } \\
\text { No }\end{array}$} & \multirow[b]{2}{*}{ Genotypes } & \multirow{2}{*}{$\begin{array}{c}\text { Days taken } \\
\text { for seed } \\
\text { germination }\end{array}$} & \multirow{2}{*}{$\begin{array}{c}\text { Percent of } \\
\text { germination }\end{array}$} & \multicolumn{2}{|c|}{ Plant height $(\mathrm{cm})$} & \multirow{2}{*}{$\begin{array}{c}\text { Number of } \\
\text { primary } \\
\text { branches } \\
\text { plant }^{-1}\end{array}$} & \multirow{2}{*}{$\begin{array}{c}\text { Days to } \\
\text { first } \\
\text { flowering }\end{array}$} & \multirow{2}{*}{$\begin{array}{c}\text { Days to } \\
50 \% \\
\text { flowering }\end{array}$} & \multirow{2}{*}{$\begin{array}{c}\text { Days to } \\
\text { first } \\
\text { picking }\end{array}$} & \multirow{2}{*}{$\begin{array}{c}\text { Days to } \\
\text { last } \\
\text { picking }\end{array}$} & \multirow{2}{*}{$\begin{array}{c}\text { Pod } \\
\text { length } \\
(\mathrm{cm})\end{array}$} & \multirow{2}{*}{$\begin{array}{c}\text { Pod } \\
\text { diameter } \\
(\mathbf{m m})\end{array}$} \\
\hline & & & & At 45 days & $\begin{array}{l}\text { At final } \\
\text { harvest }\end{array}$ & & & & & & & \\
\hline 1 & Arka Suman & 4.00 & 89.28 & 47.13 & 157.60 & 6.53 & 46.67 & 50.33 & 60.67 & 95.33 & 20.27 & 5.67 \\
\hline 2 & Arka Samrudhi & 4.67 & 90.48 & 67.40 & 256.87 & 7.53 & 48.33 & 52.67 & 61.67 & 95.67 & 22.80 & 6.20 \\
\hline 3 & Bhagyalakshmi & 5.00 & 66.67 & 37.60 & 43.47 & 4.53 & 42.33 & 45.67 & 54.67 & 83.00 & 18.73 & 4.60 \\
\hline 4 & IC-97797 & 7.00 & 76.19 & 60.33 & 111.80 & 5.07 & 45.67 & 49.33 & 58.67 & 81.00 & 19.13 & 4.74 \\
\hline 5 & IC-337932 & 6.33 & 80.95 & 61.60 & 125.47 & 5.93 & 43.67 & 47.33 & 56.33 & 92.33 & 19.07 & 4.95 \\
\hline 6 & IC-51154 & 6.00 & 72.62 & 62.20 & 128.33 & 6.07 & 43.33 & 46.67 & 55.67 & 92.67 & 21.07 & 6.42 \\
\hline 7 & IC-222810 & 6.33 & 75.00 & 57.07 & 117.33 & 5.33 & 44.33 & 48.67 & 58.33 & 85.33 & 20.20 & 6.53 \\
\hline 8 & Kashi Nidhi & 5.00 & 89.29 & 66.40 & 156.13 & 6.47 & 39.00 & 41.67 & 51.00 & 94.33 & 42.93 & 8.60 \\
\hline 9 & Kashi Shyamal & 6.00 & 77.38 & 62.60 & 131.07 & 6.13 & 42.67 & 46.67 & 55.33 & 98.00 & 30.33 & 7.40 \\
\hline 10 & Kashi Unnati & 5.67 & 82.14 & 63.40 & 138.07 & 6.27 & 39.67 & 42.33 & 52.67 & 93.67 & 40.33 & 8.20 \\
\hline 11 & Kashi Gauri & 5.33 & 78.57 & 63.20 & 144.87 & 6.20 & 41.00 & 44.67 & 53.33 & 98.00 & 31.87 & 7.33 \\
\hline 12 & $\begin{array}{l}\text { Kashi Kanchan } \\
\text { (Check) }\end{array}$ & 5.00 & 85.72 & 64.40 & 147.93 & 6.33 & 41.67 & 45.67 & 54.33 & 93.33 & 40.07 & 7.60 \\
\hline & Mean & 5.53 & 80.36 & 59.44 & 138.24 & 6.03 & 43.20 & 46.81 & 56.06 & 91.89 & 27.23 & 6.52 \\
\hline & $\mathrm{SE}(\mathrm{m})+$ & 0.20 & 2.84 & 2.07 & 2.02 & 0.16 & 0.28 & 0.38 & 0.52 & 0.57 & 0.58 & 0.19 \\
\hline & $\mathrm{CD}$ at $5 \%$ & 0.59 & 8.37 & 6.10 & 5.95 & 0.48 & 0.82 & 1.13 & 1.54 & 1.69 & 1.72 & 0.57 \\
\hline
\end{tabular}

Table 1: Continued...

\begin{tabular}{|c|c|c|c|c|c|c|c|c|c|c|c|}
\hline $\begin{array}{l}\text { S. } \\
\text { No }\end{array}$ & Genotypes & $\begin{array}{c}\text { Number } \\
\text { of pods } \\
\text { plant }^{-1}\end{array}$ & $\begin{array}{l}\text { Green pod } \\
\text { weight (g) }\end{array}$ & $\begin{array}{c}\text { Green pod } \\
\text { yield } \\
\text { plant }^{-1}(g)\end{array}$ & $\begin{array}{c}\text { Green } \\
\text { pod yield } \\
\text { plot }^{-1}(\mathrm{~kg})\end{array}$ & \begin{tabular}{|c|} 
Green \\
pod yield $^{-1}(q)$ \\
ha $^{-1}(q)$
\end{tabular} & $\begin{array}{c}\text { Total dry matter } \\
\text { accumulation } \\
\text { plant }^{-1}(\mathrm{~g})\end{array}$ & $\begin{array}{c}\text { Protein } \\
\text { content } \\
(\%)\end{array}$ & $\begin{array}{c}\text { TSS } \\
\left({ }^{\circ} \text { Brix }\right)\end{array}$ & $\mid \begin{array}{c}\text { Per cent } \\
\text { incidence of } \\
\text { pest }\end{array}$ & \begin{tabular}{|c|} 
Per cent \\
incidence of \\
disease
\end{tabular} \\
\hline 1 & Arka Suman & 60.93 & 7.07 & 287.60 & 7.61 & 126.89 & 107.33 & 3.77 & 3.34 & 12.22 & 4.03 \\
\hline 2 & Arka Samrudhi & 63.73 & 12.20 & 298.07 & 8.02 & 133.61 & 119.00 & 3.80 & 3.39 & 12.18 & 3.96 \\
\hline 3 & Bhagyalakshmi & 46.80 & 6.87 & 193.13 & 5.22 & 88.39 & 28.00 & 3.94 & 3.47 & 20.87 & 7.70 \\
\hline 4 & IC-97797 & 38.20 & 5.73 & 196.47 & 5.30 & 89.27 & 32.33 & 3.91 & 4.01 & 16.00 & 7.82 \\
\hline 5 & IC-337932 & 39.13 & 7.20 & 220.27 & 6.07 & 101.22 & 65.33 & 4.07 & 3.79 & 23.63 & 5.90 \\
\hline 6 & IC-51154 & 39.27 & 9.53 & 228.53 & 6.21 & 103.50 & 69.00 & 4.20 & 4.23 & 18.42 & 6.42 \\
\hline 7 & IC-222810 & 33.27 & 9.47 & 218.13 & 5.97 & 99.56 & 36.33 & 4.04 & 3.85 & 14.39 & 6.28 \\
\hline 8 & Kashi Nidhi & 61.73 & 21.07 & 373.20 & 9.67 & 161.17 & 99.00 & 3.88 & 4.94 & 13.24 & 5.39 \\
\hline 9 & Kashi Shyamal & 38.60 & 11.53 & 267.80 & 7.33 & 122.11 & 101.33 & 3.44 & 4.26 & 18.27 & 14.34 \\
\hline 10 & Kashi Unnati & 55.07 & 20.13 & 311.47 & 8.39 & 141.84 & 72.67 & 3.98 & 4.04 & 18.13 & 7.12 \\
\hline 11 & Kashi Gauri & 52.80 & 16.13 & 309.40 & 8.16 & 136.06 & 85.67 & 3.31 & 3.35 & 47.33 & 18.91 \\
\hline 12 & $\begin{array}{c}\text { Kashi Kanchan } \\
\text { (Check) }\end{array}$ & 61.27 & 19.40 & 338.33 & 9.02 & 152.20 & 98.33 & 3.84 & 3.99 & 17.73 & 5.82 \\
\hline
\end{tabular}




\begin{tabular}{|c|c|c|c|c|c|c|c|c|c|c|c|}
\hline & Mean & 49.23 & 12.19 & 270.20 & 7.25 & 121.32 & 76.19 & 3.85 & 3.89 & 19.37 & 7.81 \\
\hline & SE $(\mathrm{m})+$ & 1.52 & 0.48 & 9.63 & 0.20 & 2.88 & 4.47 & 0.04 & 0.11 & 3.09 & 2.00 \\
\hline & CD at 5\% & 4.49 & 1.40 & 28.44 & 0.60 & 8.49 & 13.20 & 0.13 & 0.33 & 9.13 & 5.91 \\
\hline
\end{tabular}

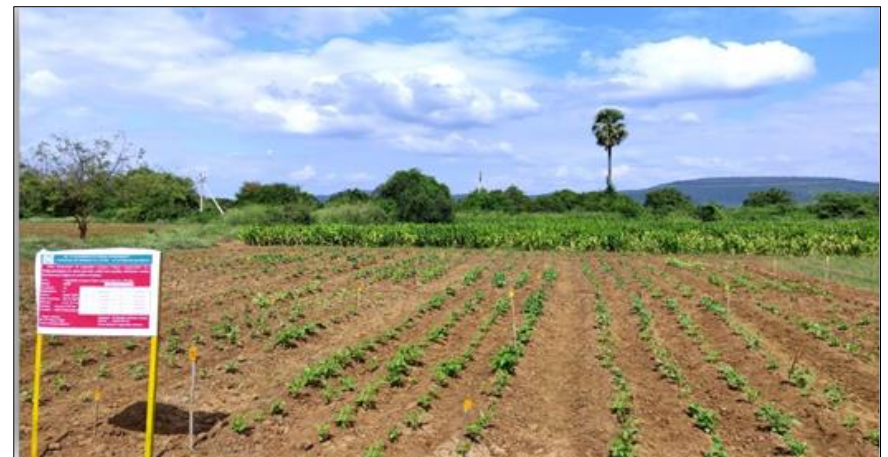

Plate 1: Experimental field view at 30 days after sowing

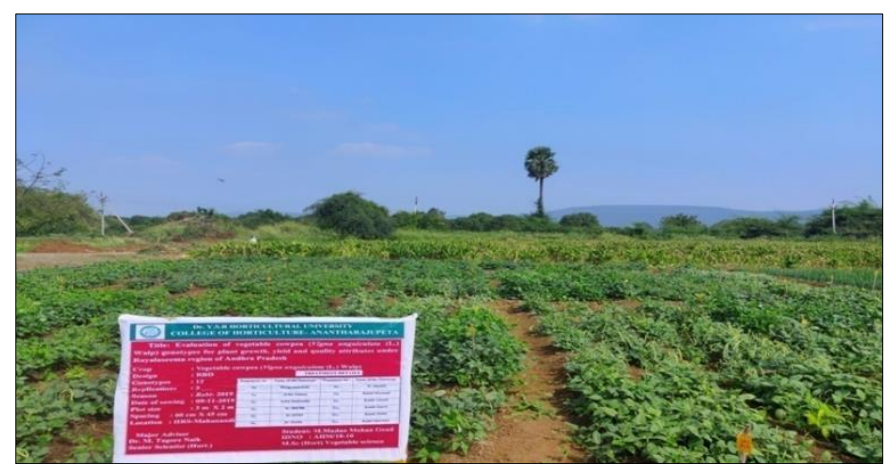

Plate 2: Experimental field view at 60 days after sowing

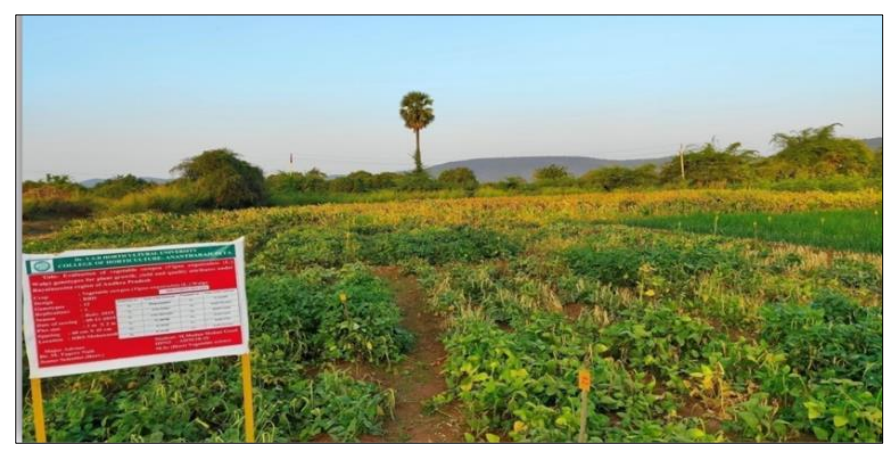

Plate 3: Experimental field view at 80 days after sowing
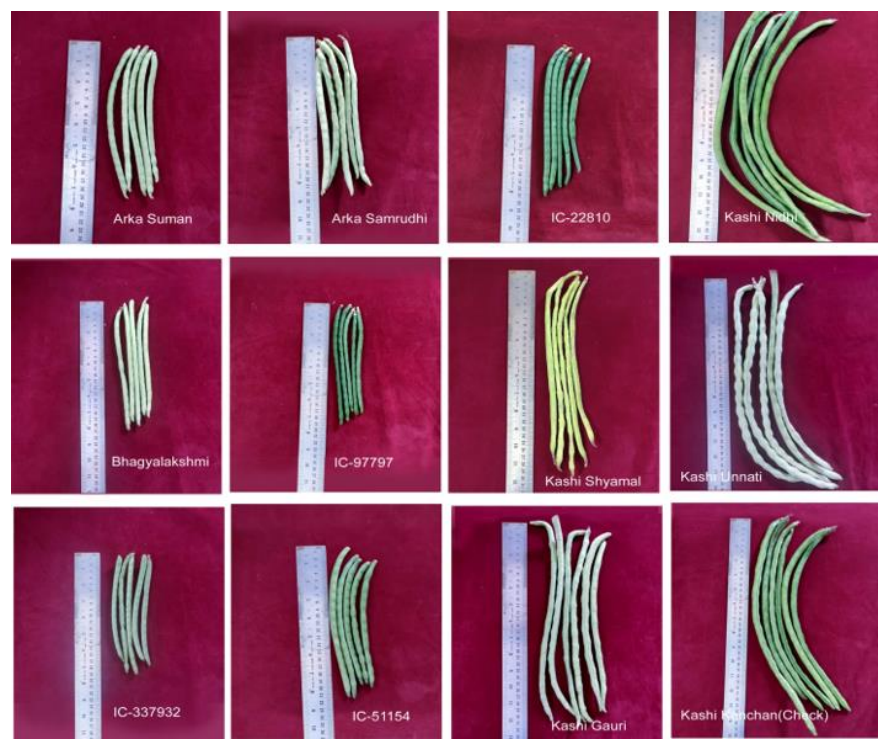

Plate 4: Variation among vegetable cowpea genotypes for pod length

\section{Conclusion}

In the present study, Kashi Nidhi is the most promising genotype with respect to yield characters and the mean values were found to be superior than the national check Kashi Kanchan for most of the characters. However, it can be concluded that Kashi Nidhi followed by check variety Kashi Kanchan and Kashi Unnati are top three ranking genotypes based on overall mean performance of all traits. Hence Kashi Nidhi, Kashi Kanchan and Kashi Unnati may be recommended for commercial cultivation in Rayalaseema region of Andhra Pradesh.

\section{References}

1. Anonymous. Agricultural Statistics at A Glance. Directorate of Economics and Statistics, Andhra Pradesh, 2018.

2. Anonymous. National Horticulture Data Base. National Horticulture Board. Ministry of Agriculture and Farmers Welfare, Government of India, 2018.

3. Bamabalwad J, Pankaja NS, Sugeetha G, Mahadev J, Suryakanth. Investigations on the rust disease prevalence on cowpea in Mandya district and Evaluation of cowpea genotypes for its resistance. International Journal of Current Microbiology and Applied Sciences. 2019; 8(11):1126-33.

4. Bhattarai C, Marasini D, Dawadi P, Aryal S. Evaluation of performances of cowpea (Vigna ungiculata) genotypes in agronomy farm of Lamjung campus. International Journal of Applied Sciences and Biotechnology. 2017; 5(3): 382-85.

5. Bose TK, Kabir J, Maity TK, Parthasarathy VA, Som MG. Vegetable Crops. Naya Udyog, Kolkata, 2003, 230.

6. Darlington CD and Wylie AP. Chromosome atlas of flowering plants. George Allen and Unwin Ltd., London, 1955.

7. Dipikaben MP, Kumari S. Varietal evaluation of vegetable cowpea (Vigna unguiculata (L.) Walp) with respect to yield under North Gujarat condition. Journal of Pharmacognosy and Phytochemistry. 2018; 7(4):424-27.

8. Dipikaben MP, Varma LR, Kumari S. Varietal evaluation of vegetable cowpea [Vigna unguiculata (L.) Walp] with respect to plant growth, flowering and fruiting behaviour under North Gujarat condition. International Journal of Current Microbiology and Applied Sciences. 2018; 7(7):3913-20.

9. Diwaker P, Sharma MK, Diwakar A, Singh P, Bhadala K and Meena S. Genetic variability assessment in vegetable cowpea [Vigna unguiculata (L.) Walp.] genotypes. International Journal of Chemical Studies. 2017; 5(5):150-55.

10. Gopalkrishnan TR. Vegetable crops. New India publishing agency, New Delhi. 2007; 4:170.

11. Gupta RK, Parmila, Arya M, Kumar A, Kumari P. Study on genetic variability in cowpea [Vigna unguiculata (L.) Walp]. Current Journal of Applied Science and Technology. 2019; 33(2): 1-8.

12. Hinge SS, Haladavanekar PC, Parulekar YR, Haldankar PM, Sawant PS, Narke S R. Evaluation of yard long bean genotypes (Vigna unguiculata Ssp. Sesquipedalis (L.) Verdcourt) grown under Konkan agroclimatic conditions 
of Maharashtra. Journal of Indian Society of Coastal agricultural Research. 2015; 33(2):49-54.

13. Madhavi K. Evaluation of vegetable cowpea (Vigna unguiculata (L.) Walp) varieties for high yield in coastal Andhra Pradesh. M.Sc (Horti) thesis, Dr. Y.S.R. Horticultural University, Venkatareamanagudem, 2012, 79-80.

14. Mal D, Datta S, Bhaisare PT, Chatterjee R, Chowdhury, A, Jana JC. Performance of cowpea varieties under zero tillage conditions in rice-wheat cropping system. Legume Research, 2018, 1-9.

15. Ng NQ, Marechal R. Cowpea taxonomy, origin and germplasm. In: Singh, S. R and Rachie, K. O. (eds) Cowpea research, production and utilization. Wiley, New York, 1985, 11-21.

16. Panse VG, Sukhatame PV. Statistical Methods for Agricultural Workers. ICAR, New Delhi, 1985.

17. Pawar Y, Varma LR, Verma $P$ and Kulkarni MV. Varietal performance of cowpea (Vigna unguiculata L.) against growth, seed yield and quality attributes. Ecology, Enviroment and Conservation. 2016; 22(3):579-82.

18. Reddy GPD, Bahadur V, Reddy PSS, Reddy MAN, Reddy GC. Evaluation and characterization of cowpea (Vigna unguiculata (L.) Walp.) genotypes for growth, yield and quality parameters. Plant Archieves. 2016; 16(2): 602-06.

19. Roy S, Sahay G, Singh UP, Soni R. Evaluation of genetic divergence in cowpea (Vigna unguiculata) for major insect pests. Indian Journal of Agricultural Sciences. 2011; 81(1): 82-85.

20. Srinivas J, Kale SV, Nagre PK. Evaluation of different cowpea varieties and genotypes. International Journal of Pure and Applied Bioscience. 2017; 5(3):329-34.

21. Vavilov NI. The origin, variation, immunity and breeding of cultivated plants. Chronica Botanica. 1949; 13:1-54. 